\title{
Experiences with evaluating two farming systems in a split herd comparison on a commercial Waikato dairy farm
}

\author{
C.B. GLASSEY ${ }^{1}$, M.B. BLACKWELL ${ }^{1}$, K.A. MACDONALD ${ }^{1}$, P.C. LAWREY ${ }^{1}$, \\ P. GEORGE ${ }^{2}$ and J. GEORGE ${ }^{2}$ \\ ${ }^{1}$ Dexcel, Private Bag 3221, Hamilton \\ ${ }^{2}$ Dairy Farmers, Parawera, RD1, Te Awamutu \\ chris.glassey@dexcel.co.nz
}

\begin{abstract}
An on-farm demonstration of the effects of a higher stocking rate (expressed as cows per hectare), supported by purchased maize silage, was conducted on a commercial Waikato dairy farm that was split into two farmlets. Milk from each farmlet was collected into separate vats. This paper reports on two seasons of comparison between:

1. A 57-ha farmlet with 185 Friesian cows stocked at 3.25 cows per ha, representing the farm's previous management (Control -LS) and;

2. A 51-ha farmlet with 185 Friesian cows stocked at 3.6 cows per ha, supported by the purchase of $430 \mathrm{~kg}$ DM per cow of maize silage (Treatment -HS)
\end{abstract}

The comparison aimed to demonstrate that higher stocking rates, supported by purchased maize silage, would increase total pasture utilisation and increase profit per hectare. Milksolids production for the HS farmlet was 105 and $99 \mathrm{~kg}$ per ha higher than LS in years one and two with Economic Farm Surplus per ha increasing by \$113-\$375 per ha (depending on payout).

The comparison highlighted the difficulty of determining stocking rate on a cows-per-ha basis for a farm with unknown pasture production. In effect, the comparison was between two herds stocked at a similar level relative to total feed supply, with both herds being limited by total feed supply. This study also demonstrated practical management issues involved for farmers who are adding purchased feed into their systems. Being a commercial dairy farm meant this split herd demonstration could not be subjected to strict scientific protocols, as the commercial objectives of the farmers had to be met. The limitations and advantages of this type of on-farm demonstration are discussed.

Keywords: economic farm surplus, maize silage, milksolids production per ha, on-farm demonstration, split-herd comparison, stocking rate

\section{Introduction}

Dexcel's Green to Gold programme is aimed at demonstrating established principles and technologies of dairy farm systems on commercial dairy farms. High levels of pasture utilisation are important in farm profitability (McGrath 1997) but this will be compromised if high pasture utilisation is achieved at the expense of milksolids production per cow. Many dairy farmers are looking to use high quality supplements in their farming systems to fill feed deficits created by the stocking rates necessary to achieve high pasture utilisation.

This paper reports on two seasons of a Green to Gold farm programme. The farm belongs to Peter and Joanne George of Parawera, south-east of Te Awamutu. The farm contour is flat to rolling with some steep sidling and is generally covered with free-draining ash soils. The drier summers of recent years and the light soils have seen the farm production limited by a lack of summer feed.

In the 3 years prior to the Green to Gold programme, the farm milked between 2.9 and 3.25 cows per ha and has produced $940 \mathrm{~kg} \mathrm{MS} / \mathrm{ha}$., except in 1998/99 due to autumn drought (Table 1). Approximately 3 ha of maize was grown on the dairy farm area for maize silage each year, and fed in late autumn, and winter.

Table 1 Production history for the farm of Peter and Joanne George.

\begin{tabular}{lccc}
\hline & $1996 / 97$ & $1997 / 98$ & $1998 / 99$ \\
\hline Max cows per ha & 2.93 & 2.94 & 3.32 \\
kg MS per cow & 320 & 318 & 248 \\
kg MS per ha & 940 & 937 & 822 \\
\hline
\end{tabular}

\section{Farmer objectives}

Peter and Joanne George listed the following objectives for themselves at the start of the programme:

1. Increase economic farm surplus.

2. Reduce debt.

3. Improve management skills. 
4. Improve lifestyle and family time.

5. Answer the question: "Are management skills or the farm environment limiting an increase in milksolids production?"

\section{Dexcel objectives}

1. Increase treatment farmlet profitability by $\$ 300 / \mathrm{ha}$ economic farm surplus.

2. Use a higher stocking rate to harvest more pasture over the spring-early summer.

3. Use maize silage for the high-stocked herd to achieve an extra 30 days lactation per cow.

4. Examine the merits of existing technology under local conditions and constraints.

How well these objectives were met and the questions answered is discussed later in the paper.

\section{Method}

The farm infrastructure meant the herd was already run as a split herd.

The Green to Gold programme involved running two systems, with milk production being collected from each system separately. One farm system was to represent the current management, and the other a change in the system. A Dexcel farm systems scientist, and the local consulting officer were available to the farmer to support the management decision making on the new system, but Dexcel's input into the decision making in the current system was kept to a minimum.

The systems chosen meant dividing the existing herd into equal halves, and splitting the farm proportionately by area, to create a difference in cows per hectare.

The maize grown on-farm would in future be purchased or grown off-farm, and used to support the high-stocked herd, thus doubling the amount of maize silage available per cow, for half the herd.

A comparison was made between:

1. A 57-ha farmlet stocked at 3.25 Friesian cows per ha, representing the farm's previous management (Control - Low stocked -LS).

2. A 51-ha farmlet stocked at 3.6 Friesian cows per ha, supported by the purchase of $430 \mathrm{~kg} \mathrm{DM} / \mathrm{cow}$ of maize silage (Treatment - High Stocked -HS).

This comparison was to test whether increased pasture utilisation with a higher stocking rate would be profitable when supported by purchased maize silage in the autumn. It was expected that this maize silage would allow more lactation days in the autumn for the HS herd rather than having to dry off cows during a summer-autumn feed deficit.
All paddocks were scored for drainage, contour and aspect and sorted to provide two similar farmlets of 51 and $57 \mathrm{ha}$. The 370 cows were scored for age, production worth and somatic cell count before being split on a random basis to give two herds of 185 cows. Dexcel technicians visited the farm monthly to record pasture cover using rising plate meters and standard daily calibration equations (Thomson et al. 2001). Pasture growth rate was measured from two cage sites on each farmlet.

The use of a commercial dairy farm for a split herd comparison meant that this comparison could not be subjected to strict scientific protocols, as the commercial objectives of the farm had to be met. It was not intended to carry out statistical analysis.

Decision rules for identifying surplus grass for silage, the commencement of supplementary feeding and drying off cows in poor condition were based on those developed at Dairying Research Corporation (Macdonald \& Penno 1998). Recommendations were made to the farm owners based on these decision rules. In year one, $132 \mathrm{~kg} \mathrm{DM} / \mathrm{cow}$ was harvested as surplus for the LS herd and $112 \mathrm{~kg} \mathrm{DM} /$ cow for the HS herd. In year two, there was no surplus grass harvested on either treatment, but the control group had 4 ha of pasture removed for a turnip crop.

The 1999/2000 farm accounts and the Dexcel ProfitWatch programme were used for an economic evaluation. Care was taken to allocate costs to the farmlets where they occurred. As accounts are not yet finalised for the 2000/2001 season, economic performance measures are not provided, but estimates are made based on the difference in physical performance and the estimated costs.

\section{Results}

Results are evaluated in terms of milksolids production (kg MS per cow and per ha), and profitability by economic farm surplus (EFS) per ha, and return on capital (including extra capital and excluding capital appreciation) (Table 2).

\section{$1999 / 2000$ season}

The HS farmlet produced an extra $105 \mathrm{~kg}$ milksolids per ha, which resulted in an increased economic farm surplus of $\$ 113$ per ha at a payout of $\$ 3.75 / \mathrm{kg}$ milksolids.

Eighty-five percent of the difference in milksolids per ha was derived from the period before supplement was fed. From the start of calving in year one, there was an immediate response to the increased stocking rate. The $11 \%$ increase in cows per ha. was reflected in a constant $10-13 \%$ increase in daily production 
Table $\llbracket 2$ Milksolids production, feed and economic performance for the two seasons of split herd comparison.

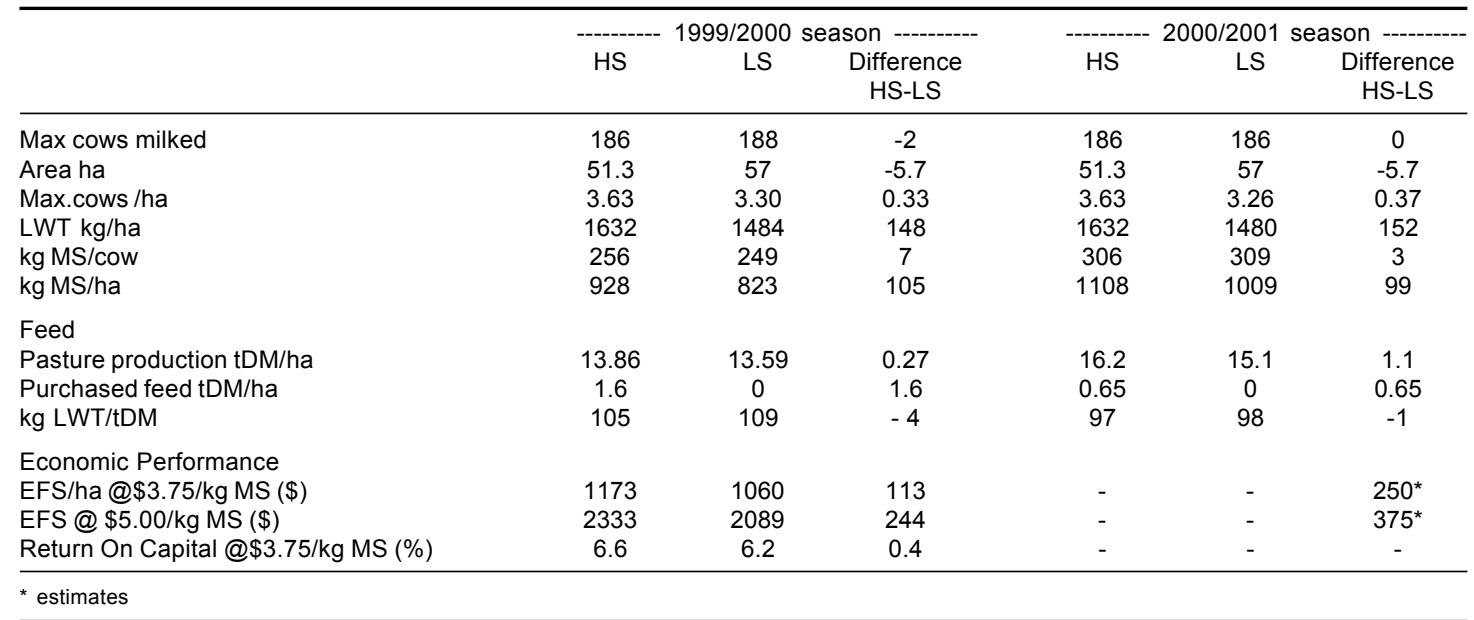

right through the season (Figure 1). Despite the increased cows per ha, and increased production there was still an opportunity to harvest $112 \mathrm{~kg} \mathrm{DM} / \mathrm{cow}$ of pasture silage in early November. On 11 February, pasture silage was offered to the HS herd at $4 \mathrm{~kg} \mathrm{DM} /$ cow/day. On 11 March, maize silage (80 tonnes DM) became available and was phased in as the pasture silage ran out. Conditions remained dry so there was insufficient pasture to support the supplement, and the herd was dried off on 15 April. Maize silage was fed to dry cows until 7 June when supplies ran out. The LS herd was fed pasture silage from 11 March until the herd was dried off on 9 April.

Conditions in April 2000 were such that the maizefed HS herd was dried off within a week of the LS herd, resulting in only 4 extra milking days per cow for the supplemented herd. The result was that in the first year, there was little impact from the maize on milksolids production.

\section{0/01 season}

Milksolids production per ha increased over the previous season by $19 \%$ for the HS herd and $23 \%$ for the LS herd. The difference between the two systems was slightly less than the previous season (99 versus $105 \mathrm{~kg} \mathrm{MS} / \mathrm{ha}$ ). Production per cow increased by $50 \mathrm{~kg} \mathrm{MS} / \mathrm{cow}$ for the HS herd and $60 \mathrm{~kg}$ MS per cow for the LS herd over the previous season (Table 2).

The HS herd was reduced by early culling of 18 cows in November due to a feed shortage (Figure 2). The planned maize silage resource had all been utilised in the previous autumn so the option was to purchase more feed or drop the stocking rate. This decision could be seen to compromise the comparison and
Figure $\llbracket 1$ Milksolids production per ha per day for the two farmlets in the $1999 / 2000$ season.

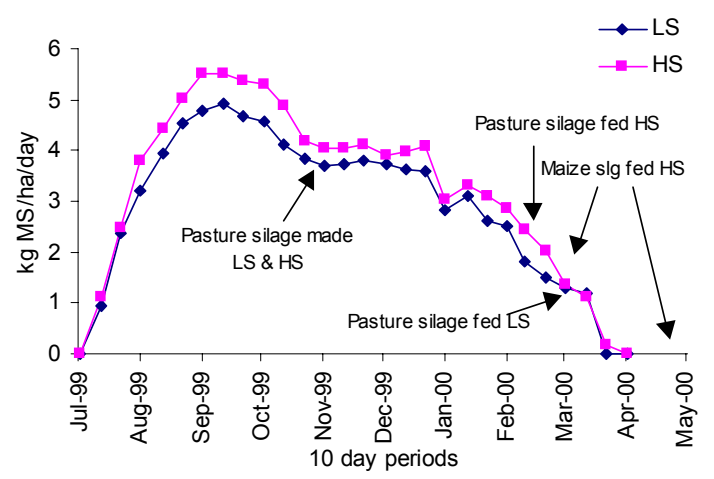

Figure $\llbracket 2$ Milksolids production per ha per day for the two farmlets in the 2000/2001 season.

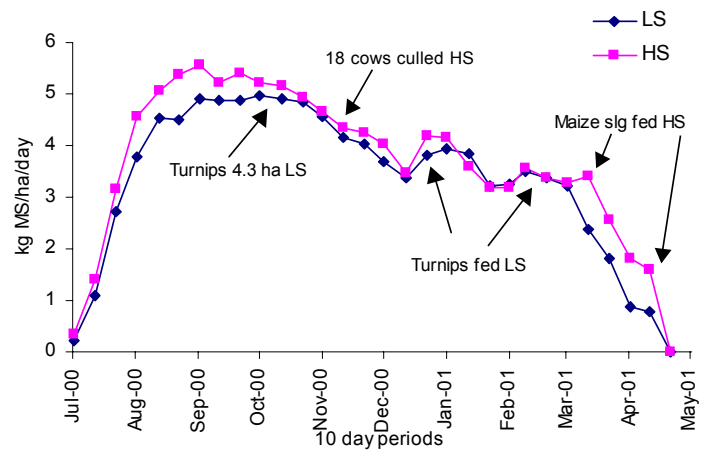

raises questions about the sustainability of the stocking rates (cows per ha) chosen for comparison.

Milksolids production per ha per day was similar for the two systems from November until late March 
when maize silage feeding was able to start for the HS herd (Figure 2). The result was that more cows remained in milk during April and into May compared to the LS herd.

Annual pasture production measured by cage cuts increased by $16 \%$ from year one to year two for the HS farmlet and $8 \%$ for the LS farmlet.

The reasons for the increase in EFS difference (Table 2) between year one and year two are:

1. Higher milksolids production for both systems.

2. Reduced consumption of maize silage in year two. The EFS is calculated on a feed used basis, with the maize silage used in that year costed in that financial year. In year one this occurred with all the maize silage consumed within 3 months of purchase.

\section{Discussion}

An increase in milksolids production and economic farm surplus has resulted from increasing the stocking rate and supporting that with the purchase of maize silage. It is important to note that this response came not from the direct feeding of supplement but from the change to the whole farm system, particularly more cows per ha. This is demonstrated by the milksolids production profiles for each farmlet in Figures 1 and 2. Most of the gain in milksolids production per ha occurred outside the period when maize silage was being fed, with small gains being made due to maize silage feeding towards the end of the second year.

The level of milksolids per cow for both farmlets, and the lack of surplus pasture for both herds in the spring of 2000, suggest that the stocking rates relative to the total feed supply are high. Stocking rates for 1999/2000, expressed as $\mathrm{kg} \mathrm{LWT/t} \mathrm{DM} \mathrm{were} 105$ and 109 respectively, above the optimum level of $85 \mathrm{~kg}$ LWT/t DM identified by Penno (1999). In effect, the comparison has been between two herds stocked at a similar level relative to total feed supply, with both herds being limited by total feed supply. In the second year, increased annual pasture production resulted in more feed available and production per cow increased by $50-60 \mathrm{~kg} \mathrm{MS} /$ cow to just over $300 \mathrm{~kg} \mathrm{MS} /$ cow. The ratio of liveweight to feed supply fell below $100 \mathrm{~kg}$ LWT/t DM. This is still above the published optimum and suggests there is plenty of scope to either increase feed supply or reduce cows per ha in an effort to increase production per cow to $350 \mathrm{~kg}$ MS per cow.

The comparison highlights the difficulty of determining stocking rate on a cows-per-ha basis for a farm with unknown pasture production. The variation
Figure 43 Two seasons' average pasture cover (APC) for LS farmlet

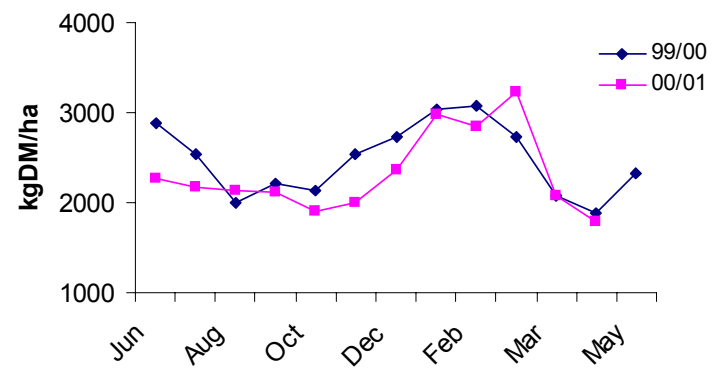

Figure $\llbracket 4$ Two seasons' average pasture cover (APC) for HS farmlet.

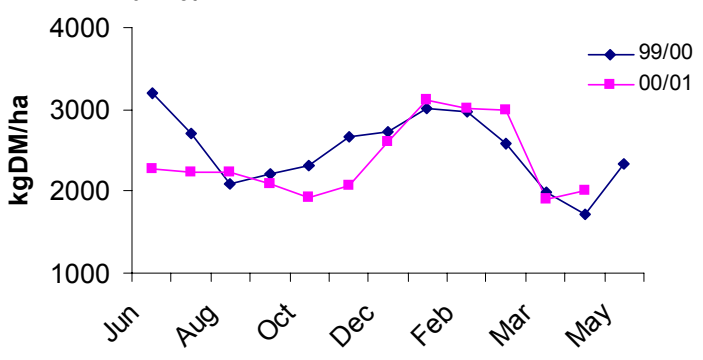

in pasture production recorded between the two years also shows the difficulty farmers have in choosing appropriate stocking rates.

The choice of increasing cows per ha. for the HS systems was based on demonstrating that harvesting a higher proportion of the grass grown in the spring, and supporting that with supplements, was a preferred option to previous management. The demonstration showed that there was surplus grass to be captured at certain times of the year (Figure 3). In the short term, it could be economically turned into extra milksolids, but if the higher stocking rate was to be sustained, then the issue of the amount and timing of supplement would need to be better addressed than they were in this instance.

A farmer moving towards this strategy needs to consider the following:

1. Contingencies to allow for feed deficits before the planned supplement becomes available. Purchasing $430 \mathrm{~kg} \mathrm{DM} / \mathrm{cow}$ in the autumn prior to the increase in stocking rate needed to be considered in this study. This would have allowed some of the following year's maize silage to be carried through to cover the period when a decision had to be made to cull cows.

2. The timing of and the amount of supplement. Over two seasons, $860 \mathrm{~kg} \mathrm{DM} / \mathrm{cow}$ of maize silage was to be fed to increase lactation length and production. 
In total only $320 \mathrm{~kg} \mathrm{DM} / \mathrm{cow}$ (37\% of planned) was fed to lactating cows, the remainder was fed to dry cows or carried over beyond the demonstration. This reduced the milksolids response to the supplement.

\section{Outcomes in relation to farmer and Dexcel objectives}

\section{Farmer objectives}

1. Economic farm surplus has increased by up to $\$ 250$ per ha at a $\$ 3.75 / \mathrm{kg}$ milksolids payout.

2. Reduce debt. Not measured.

3. Improve management skills. Peter and Joanne George are now more familiar with the management associated with running 3.6 cows per ha and the use of maize silage to support that. They realise the need to better balance the annual feed supply with the feed demand, and to use supplements at more appropriate times.

Maize silage will be increased to $550 \mathrm{~kg} \mathrm{DM} /$ cow on the George property for the coming season at $3.4 \mathrm{cows} / \mathrm{ha}$. This is aimed at achieving $90 \mathrm{~kg}$ LWT/t DM.

4. Improve lifestyle and family time: No measures were made for this objective.

5. The demonstration clearly showed that the farm itself was not limiting and that a change in management accompanied by sufficient feed could result in production increases to more than $1100 \mathrm{~kg} \mathrm{MS} / \mathrm{ha}$.

\section{Dexcel's objectives}

1. The increase in EFS was $\$ 125 /$ ha less than anticipated. In each season the expected benefits from extending the lactation using the maize silage were less than expected. Reasons for this appear to be the overall high stocking rate relative to feed supply, and adverse autumn conditions, particularly in the first season. An increase in EFS to the level of that sought $(\$ 375 / \mathrm{ha})$ is achievable, and would require the 30 extra lactation days yielding $\$ 300$ / day towards economic farm surplus. To cover the risk of drought, an estimated extra 27 tonnes of dry matter of supplement was required, a cost of $\$ 5400$ at $\$ 0.20$ cents $/ \mathrm{kg} \mathrm{DM}$. This cost could be considered a capital cost associated with managing the risk during a change in farming systems and farmers need to consider how they manage this risk.

2. Increasing cows-per-ha resulted in more pasture harvested by the cows in the spring- early summer period turned into extra milksolids.

3. The purchase of $400 \mathrm{~kg} \mathrm{DM} / \mathrm{cow}$ of maize silage did not result in 30 extra lactation days per cow. In year one, this was due to insufficient pasture available in April/May to feed with the maize silage in order to support milk production. In year two, $180 \mathrm{~kg} \mathrm{DM} /$ cow as maize silage was fed to milking cows throughout April and into May resulting in additional lactation days per hectare for the HS herd.

4. The demonstration did confirm that existing technology from research trials was applicable to local conditions. Most obvious was that increasing cows per ha. resulted in more pasture utilised for milk production. Changing cows per ha. can also change the ratio $\mathrm{kg} \mathrm{LWT} / \mathrm{t} \mathrm{DM}$, and this was not accounted for well at the start of the demonstration.

Some advantages and disadvantages of this type of demonstration became evident. Advantages included:

1. Information is gathered about the application of farming systems in a particular environment. The farmer is able to make a more informed decision about the preferred system. Areas are exposed where misunderstandings of detail of farming systems exist (e.g., expression of stocking rate), which are useful lessons for research and extension organisations.

2. Real life data that impact on the bottom line of a commercial farm.

Disadvantages:

1. Scientific protocols are difficult to adhere to. The farmer participants are observing every day the results of the two farm systems and the impact on their financial position. They develop their own view of which works better. This creates a desire to proceed with a system rather than test further alternatives.

2. Commercial decisions influence the outcome of commercial on-farm trials. For example, the dry autumn in 1999 eliminated the maize silage that could have been carried into the trial. At the end of the trial, the high value of cows influenced decisions on future stocking rates, when a revision of the stocking rates was appropriate.

\section{Conclusion}

The comparison highlights the difficulty of determining stocking rate on a cows-per-ha basis for a farm with unknown pasture production. Adding a known amount of supplement to an unknown amount of pasture does not mean that the balance between feed supply and feed demand is correct and can result in inefficiencies. This could explain why profitability in terms of EFS was not as high as expected and longer lactations for the maize silage system were not easily achieved. 
Determining stocking rate for the farm systems by estimating expected $\mathrm{kg}$ LWT/t DM would have enhanced this demonstration, and is expected to help improve decisions where dairy farmers are looking to change annual feed supply and feed demand.

\section{REFERENCES}

Macdonald, K.A.; Penno, J.W. 1998. Management decision rules to optimise milksolids production on dairy farms. Proceedings of the New Zealand Society of Animal Production 58: 132-135.

McGrath, J. 1997. Farming for High Profit. Proceedings of the 49th Ruakura Farmers' Conference 49: 20-28.
Penno, J.W. 1999. Stocking rate for optimum profit. Proceedings of the South Island Dairy Event 1: 20-28.

Thomson, N.A.; Upsdell, M; Hooper, R; Henderson, H; Blackwell, M.B; McCallum, D.A.; Hainsworth, R.J.; Macdonald, K.A.; Wildermoth, D.; BishopHurley, G.; Penno, J.W. 2001. Development and evaluation of a standardised means for estimating herbage mass of dairy pastures using the rising plate meter. Proceedings of the New Zealand Grassland Association 63: 149-157. 